\title{
Possible targeting of $G$ protein coupled receptors to manipulate inflammation in vivo using synthetic and natural ligands
}

\author{
J F Kinsel, M V Sitkovsky
}

Ann Rheum Dis 2003;62(Suppl II):ii22-ii24

Cyclic AMP elevating Gs protein coupled receptors were considered for a long time to be immunosuppressive. One of these receptors, adenosine $A_{2 A}$ receptor, was implicated in a physiological mechanism that down regulates inflammation and protects tissues from excessive immune mediated damage. Targeting of these receptors by selective agonists may lead to better protocols of anti-inflammatory treatments. At the same time inhibiting the $\mathrm{Gs}$ protein coupled mediated signalling with antagonists could be explored in studies of approaches to enhance inflammation and tissue damage. Enhancement of targeted tissue damage is highly desirable when it is cancerous tissue, while enhancement of inflammatory events might be desirable in the development of new vaccine adjuvants.

$\mathrm{T}$ he need to control inflammation is obvious because prolonged or inappropriate inflammatory responses contribute to the pathogenesis of many major diseases associated with inflammation. ${ }^{1-5}$ To harness the body's own natural ability to down regulate inflammation, there is a need to identify endogenous anti-inflammatory pathways. Thus, it is important to identify the molecules that can not only block inflammation but that also play a part in the physiological "sensory" mechanism that recognises when an inflammatory response is damaging rather then beneficial.

One potential candidate among many cyclic AMP elevating Gs protein coupled receptors which may function as the sensory reporter of tissue damage is the $\mathrm{A}_{2 \mathrm{~A}}$ adenosine receptor. It has been known for some time that inflammatory tissue damage is accompanied by the accumulation of extracellular adenosine in inflamed areas owing to its release into the extracellular space by a variety of cells (reviewed by Linden ${ }^{6}$ ); this is a consequence of local tissue hypoxia caused by inflammatory stimuli. ${ }^{7-9}$ Moreover, it is now well established that activation of $A_{2 A}$ receptors $\left(A_{2 A} R s\right)$ on lymphoid cells induced by extracellular adenosine leads to inhibition of an inflammatory response, ${ }^{10-15}$ and this is due in large degree to its ability to induce accumulation of intracellular cAMP in activated immune cells. More recently, the use of $\mathrm{A}_{2 \mathrm{~A}} \mathrm{R}$ deficient mice has illustrated that the $\mathrm{A}_{2 \mathrm{~A}} \mathrm{R}$ is a critical inflammatory "OFF" button, which is necessary for the inhibition of inflammation and protection from tissue damage. ${ }^{16}$ Thus, $\mathrm{A}_{2 \mathrm{~A}} \mathrm{Rs}$ are promising targets in manipulating the inflammatory response.

Adenosine receptors are members of the family of seven transmembrane G protein coupled receptors. The structure, function, and basis for classification of adenosine receptors and their genes are reviewed by Fredholm et al. ${ }^{17}{ }^{18}$ The four known adenosine receptors, $\mathrm{A}_{1}, \mathrm{~A}_{2 \mathrm{~A}}, \mathrm{~A}_{2 \mathrm{~B}}$, and $\mathrm{A}_{3}$ subtypes, have all been characterised and cloned from a variety of species, including rat, mouse, and human. ${ }^{79-21}$ Among mammals, the receptors of the same subtype exhibit close similarity. ${ }^{18}$ Adenosine receptor distribution is heterogeneous (summarised in Fredholm et $a^{17}{ }^{17}$. Most data available concern $\mathrm{A}_{1}$ and $\mathrm{A}_{2 \mathrm{~A}}$ receptors because better pharmacological tools are available for detecting those receptors. The $A_{2 A} R$ subtype is highly expressed on lymphoid tissues, including the spleen, thymus, leucocytes, and blood platelets.

In general, $A_{1}$ and $A_{3}$ receptors are coupled to $\mathrm{Go}$ and $\mathrm{Gi}$ proteins, ${ }^{22-26}$ and $A_{2 A}$ and $A_{2 B}$ receptors interact with Gs proteins. ${ }^{27}{ }^{28}$ In addition, some evidence suggests that adenosine receptors may use other $G$ proteins. For example, $A_{2 A} R s$ may couple with different $G$ proteins in diverse places such as $G_{\text {off }}$ in the striatum, ${ }^{29}$ and $A_{2 B}$ receptors also link to $\mathrm{Gq}$ in some cells. ${ }^{21}{ }^{30}$ By virtue of their interaction with their respective $G$ proteins $\mathrm{A}_{2 \mathrm{~A}}$ and $\mathrm{A}_{2 \mathrm{~B}}$ activate adenylyl cyclase, ${ }^{27-29}$ resulting in the accumulation of cAMP. Activation of $A_{1}$ and $A_{3}$ receptors inhibits CAMP accumulation. ${ }^{23} 26$

It has been well established that pharmacological activation of $\mathrm{A}_{2 \mathrm{~A}} \mathrm{Rs}$ on lymphoid cells stimulates an anti-inflammatory response. ${ }^{11}{ }^{12}{ }^{14-16}$ Investigations into the role of extracellular adenosine have shown that this physiologically abundant molecule triggers strong immunosuppressive responses in $\mathrm{T}$ cells, mediated by cAMP, by acting through the Gs protein coupled $\mathrm{A}_{2 \mathrm{~A}}$ adenosine receptors (reviewed by Gomez et a $^{31}$ ). In addition, the inhibitory effects of adenosine on the secretion of proinflammatory cytokines by a variety of other cell types, most notably monocytes and macrophages, have been extensively documented. ${ }^{132-38}$

In a study using $A_{2 A} R$ deficient mice, the first strong evidence for the critical role of $A_{2 A} R s$ in the regulation of inflammation in vivo has been shown. ${ }^{16}$ This study demonstrates that absence of the $A_{2 A} R$ results in enhanced inflammation and increased tissue damage in models of acute liver damage, endotoxin induced sepsis, and infected wound model. This clearly establishes $\mathrm{A}_{2 \mathrm{~A}} \mathrm{Rs}$ as negative regulatory receptors of inflammation. Moreover, it illustrates a physiological immunosuppressive loop, in which disturbance of local tissue environment by inflammatory stimuli results in local hypoxia and the accumulation of extracellular adenosine; this, in turn, suppresses inflammation in a negative feedback manner by triggering the accumulation of cAMP through $A_{2 A} R$ signalling.

The down regulation of the immune response mediated by $\mathrm{A}_{2 \mathrm{~A}}$ Rs is, however, potentially dangerous, despite the beneficial aspects of halting tissue damage and inflammation. The premature inhibition of immune cell function may allow pathogens to survive, and the overall damage to the organism will be greater. On the other hand, the lack of $\mathrm{A}_{2 \mathrm{~A}} \mathrm{R}$ signalling may lead to excessive damage, with important biological consequences. Thus, the expression and function of $\mathrm{A}_{2 \mathrm{~A}} \mathrm{Rs}$ should be tightly regulated. Recent studies by Armstrong et al demonstrate that there is no receptor reserve in Tlymphocytes because $\mathrm{A}_{2 \mathrm{~A}} \mathrm{R}^{+/-}$mice had half of the total receptors compared with $\mathrm{A}_{2 \mathrm{~A}} \mathrm{R}^{+/+}$mice and only half of the maximal functional 
response. ${ }^{39}$ Thus, a balance between the need to destroy invading pathogens and the desire to protect tissue from excessive damage ultimately may be dependent on the numbers and level of activation of $A_{2 A}$ Rs in individual immune cells.

The identification of $A_{2 A} R$ signalling as a physiological pathway for the regulation of inflammation in vivo suggests that targeting of these receptors to manipulate or "engineer" the inflammatory process may have potential therapeutic implications. It is appealing to recruit "natural" anti-inflammatory mechanisms involving cAMP elevating Gs protein coupled receptors to protect tissues from excessive inflammatory damage. Under certain conditions it may be beneficial to augment or prolong selected aspects of an inflammatory process in order to destroy the causative agent, and inhibition of antiinflammatory pathways may be a therapeutic approach. In principle, the enhancement or inhibition of inflammation might be accomplished through the design and use of more highly selective pharmacological agonists and antagonists. The treatment of a wide range of diseases, including wound healing, ${ }^{40}{ }^{41}$ rheumatoid arthritis, ${ }^{42}$ and sepsis, ${ }^{16}$ may benefit from targeted triggering of $A_{2 \mathrm{~A}}$ Rs. For example, methotrexate, which is used as the standard treatment for rheumatoid arthritis, has been shown to recruit this pathway by employing the use of endogenous adenosine. ${ }^{43}$ Processes that rely on an enhanced inflammation response, such as vaccination, might also benefit from selective targeting. Accordingly, these findings point to the need for more detailed studies of $\mathrm{A}_{2 \mathrm{~A}} \mathrm{R}$ agonists as recruiters of natural pathways in the treatment of acute and possibly chronic inflammatory processes.

The exacerbation of targeted tissue damage by antagonists of adenosine receptors ${ }^{16}$ in models of fulminant and viral hepatitis, as well as in a model of Pseudomonas exotoxin A induced liver injury, points to the probable use of antagonists to achieve targeted destruction of tissues and/or targeted enhancement of local immune response in relevant clinical settings. These settings may include the enhancement of antitumour immune response or development of better vaccines, or both. These considerations also should include both the synthetic and natural substances that can antagonise adenosine receptors. One such compound is 1, 3, 7-trimethylxanthine (caffeine), which is one of the most widely habitually used psychostimulants. The use of caffeine as a psychostimulant is due to its interference with signalling through adenosine receptors. ${ }^{17}{ }^{18}$ However, substances containing caffeine are also used as treatments in complementary and alternative medicine, including the Gonzalez protocol, in which coffee enemas are an integral part of a proposed regimen for treatment of pancreatic cancer. ${ }^{44}$ Thus, recognition of the role of $\mathrm{A}_{2 \mathrm{~A}}$ adenosine receptors may provide a rational basis for the analysis of sporadic reports and claims of the therapeutic effects of caffeine.

In summary, the goal of identifying targets for therapeutic modulation can be facilitated by uncovering endogenous mechanisms that stop inflammation. This is greatly facilitated by findings that extracellular adenosine may function as an endogenous "OFF" signal. With this knowledge, it is now possible to engineer (both inhibit and enhance) inflammation by engaging the $A_{2 A} R$ mediated pathway.

\section{Authors' affiliations}

\section{J F Kinsel, M V Sitkovsky}

This paper was prepared as an approved outside activity while $\mathrm{Dr}$ Sitkovsky was on leave from the Laboratory of Immunology, National Institute of Allergy and Infectious Diseases, National Institutes of Health, 10/11N311, 10 Center Drive-MSC 1892, Bethesda, MD 20892-1892, USA

Correspondence to: Dr M V Sitkovsky; mvsitkov@helix.nih.gov

\section{REFERENCES}

1 Shacter E, Weitzman SA. Chronic inflammation and cancer. Oncology (Huntingt) 2002;16:217-32.

2 McPherson JA, Barringhaus KG, Bishop GG, Sanders JM, Rieger JM Hesselbacher $S E$, et al. Adenosine A2A receptor stimulation reduces inflammation and neointimal growth in a murine carotid ligation model. Arterioscler Thromb Vasc Biol 2001;21:791-6.

3 Pockley AG. Heat shock proteins, inflammation, and cardiovascular disease. Circulation 2002;105:1012-17.

4 Shebuski RJ, Kilgore KS. Role of inflammatory mediators in thrombogenesis. J Pharmacol Exp Ther 2002;300:729-35.

5 Mulvihill NT, Foley JB. Inflammation in acute coronary syndromes. Heart 2002;87:201-4.

6 Linden J. Molecular approach to adenosine receptors: receptor-mediated mechanisms of tissue protection. Ann Rev Pharmacol Toxicol 2001;41:775-87

7 Van Belle H, Goossens F, Wynants J. Formation and release of purine catabolites during hypoperfusion, anoxia, and ischemia. Am J Pathol 1987;252:H886-93

8 Winn HR, Rubio R, Curnish RR, Berne RM. Changes in regional cerebral blood flow (rCBF) caused by increase in CSF concentrations of adenosine and 2-chloroadenosine (CHL-ADO). J Cereb Blood Flow Metab $1981 ; 1: 401$

9 Rudolphi KA, Shubert P. Adenosine and brain ischemia In: Bellardinelli $\mathrm{L}$, Pelleg A eds. Adenosine and adenine nucleotides: from molecular biology to integrative physiology. Norwell: Kluwer, 1995:391-7.

10 Cronstein BN. Adenosine, an endogenous anti-inflammatory agent. J Appl Physiol 1994;76:5-13.

11 Firestein GS. Anti-inflammatory effects of adenosine kinase inhibitors in acute and chronic inflammation. Drug Dev Res 1996;39:371-6.

12 Eigler A, Greten TF, Sinha B, Haslberger C, Sullivan GW, Endres S. Endogenous adenosine curtails lipopolysaccharide-stimulated tumour necrosis factor synthesis. Scand J Immunol 1997:45:132-9.

13 Sullivan GW, Linden J. Role of A2A adenosine receptors in inflammation. Drug Dev Res 1998;45:103-12.

14 Huang S, Koshiba M, Apasov S, Sitkovsky M. Role of A2A adenosine receptor-mediated signaling in inhibition of T-cell activation and expansion. Blood 1997;90:1600-10.

15 Koshiba M, Kojima H, Huang S, Apasov S, Sitkovsky MV. Memory of extracellular adenosine/A2A purinergic receptor-mediated signalling in murine T-cells. J Biol Chem 1997;272:25881.

16 Ohta A, Sitkovsky M. Role of G protein-coupled adenosine receptors in down-regulation of inflammation and protection from tissue damage. Nature 2001;414:916-20.

17 Fredholm BB, ljzerman AP, Jacobson KA, Klotz KN, Linden J. International Union of Pharmacology. XXV. Nomenclature and classification of adenosine receptors. Pharmacol Rev 2001;53:527-52.

18 Fredholm BB, Arslan, G, Halldner L, Kull B, Schulte G, Wasserman W. Structure and function of adenosine receptors and their genes. Naunyn Schmiedebergs Arch Pharmacol 2000;362:364-74.

19 Libert F, Parmentier M, Lefort A, Dinsart C, Van Sande J, Maenhaut C, et al. Selective amplification and cloning of four new members of the $G$ protein-coupled receptor family. Science 1989;244:569-72.

20 Olah ME, Stiles GL. Adenosine receptor subtypes: characterization and therapeutic regulation. Ann Rev Pharmacol Toxicol 1995;35:581-606.

21 Linden J, Thai T, Figler H, Robeva AS. Characterization of human A2B adenosine receptors: radioligand binding, Western blotting and coupling to $\mathrm{G}(\mathrm{q})$ in HEK-293 and HMC-1 mast cells. Mol Pharmacol 1999;56:705-13.

22 Jockers $\mathbf{R}$, Linder $M E$, Hohenegger $M$, Nanoff $C$, Bertin B, Strosberg AD, et al. Species difference in the $G$ protein selectivity of the human and bovine Al-adenosine receptor. J Biol Chem 1994;269:32077-84.

23 Akbar M, Okajima F, Tomura H, Shimegi S, Kondo Y. A single species of $\mathrm{Al}$ adenosine receptor expressed in Chinese hamster ovary cells not only inhibits CAMP accumulation but also stimulates phospholipase $\mathrm{C}$ and arachidonate release. Mol Pharmacol 1994;45:1036-42.

24 Freund S, Ungerer M, Lohse $M$. Al adenosine receptors expressed in $\mathrm{CHO}$-cells couple to adenylyl cyclase and to phospholipase C. Naunyn Schmiedebergs Arch Pharmacol 1994;350:49-56.

25 Gerwins P, Fredholm BB. Activation of adenosine Al and bradykinin receptors increases protein kinase $C$ and phospholipase $D$ activity in smooth muscle cells. Naunyn Schmiedebergs Arch Pharmacol 1995;351:186-93.

26 Palmer TM, Gettys TW, Stiles GL. Differential interaction with and regulation of multiple G-proteins by the rat $\mathrm{A} 3$ adenosine receptor. J Biol Chem 1995;270:16895-902.

27 Olah ME. Identification of A2B adenosine receptor domains involved in selective coupling to $G$ s: analysis of chimeric $A 1 / A 2 A$ adenosine receptors. J Biol Chem 1997;272:337-44.

28 Pierce KD, Furlong TJ, Selbie LA, Shine J. Molecular cloning and expression of an adenosine receptor from human brain. Biochem Biophys Res Commun 1992; 187:86-93.

29 Kull B, Svenningsson P, Fredholm BB. Adenosine A2A receptors are colocalized with and activate $G$ off in rat striatum. Mol Pharmacol 2000;58:771-7.

30 Gao Z, Chen T, Weber M, Linden J. A2B adenosine and P2Y2 receptors stimulate mitogen-activated protein kinase in human embryonic kidney-293 cells: cross-talk between cyclic AMP and protein kinase C pathways. J Biol Chem 1999;274:5972-80.

31 Gomez G, Apasov S, Sitkovsky MV. Immunosuppressive effects of extracellular adenosine on immune cells: implications for the pathogenesis of ADA SCID and immunomodulation. Drug Dev Res 2001;53:218-24. 
32 Parmely MJ, Zhou WW, Edwards ICK, Borcherding DR, Silverstein R, Morrison DC. Adenosine and a related carbocyclic nucleoside analogue selectively inhibit tumor necrosis factor- production and protect mice against endotoxin challenge. J Immunol 1993;151:389-96.

33 Bouma MG Stad RK, Wildenberg FAJMvd, Buurman WA. Differential regulatory effects of adenosine on cytokine release by activated human monocytes. J Immunol 1994;153:4159-68.

34 Hasko G, Szabo C, Nemeth ZH, Kvetan V, Pastores SM, Vizi ES Adenosine receptor agonists differentially regulate IL-10, TNF- $\alpha$ and nitric oxide production in RAW 264.7 macrophages and in endotoxemic mice. J Immunol 1996;157:4634-40.

35 Hasko G, Nemeth ZH, Vizi ES, Salzman AL, Szabo C. An agonist of adenosine $\mathrm{A} 3$ receptors decreases interleukin-12 and interferonproduction and prevents lethality in endotoxemic mice. Eur J Pharmacol 1998:358:261-8.

36 McWhinney CD, Dudley MW, Bowlin TL, Peet NP, Schook L, Bradshaw $M$, et al. Activation of adenosine $A 3$ receptors on macrophages inhibits tumor necrosis factor. Eur J Pharmacol 1996;310:209-16.

37 Saijadi FG, Takabayashi K, Foster AC, Domingo RC, Firestein GS. Inhibition of TNF- $\alpha$ expression by adenosine: role of $A 3$ adenosine receptors. J Immunol 1996; 156:3435-42.

38 Link AA, Kino T, Worth JA, McGuire JL, Crane ML, Chrousos GP, et al. Ligand-activation of the adenosine A2A receptors inhibits IL-12 production by human monocytes. J Immunol 2000;164:436-442.
39 Armstrong JM, Chen JF, Schwarzschild MA, Apasov S, Smith PT Caldwell C, et al. Gene dose effect reveals no Gs protein-coupled A2A adenosine receptor reserve in murine T-lymphocytes: studies of cells from A2A receptor gene-deficient mice. Biochem J 2001;354: 123-30.

40 Montesinos MC, Gadangi P, Longaker M, Sung J, Levine J, Nilsen D, et al. Wound healing is accelerated by agonists of A2 (G alpha s-linked) receptors. J Exp Med 1997; 186:1615-20.

41 Montesinos MC, Desai A, Chen JF, Yee H, Schwarzschild MA, Fink JS, et al. Adenosine promotes wound healing and mediates angiogenesis in response to tissue injury via occupancy of A2A receptors. Am J Pathol 2002; 160:2009-18.

42 Montesinos MC, Yap JS, Desai A, Posadas I, McCrary CT, Cronstein $\mathrm{BN}$. Reversal of the antiinflammatory effects of methotrexate by the nonselective adenosine receptor antagonist theophylline and caffeine: evidence that the antiinflammatory effects of methotrexate are mediated via multiple adenosine receptors in rat adjuvant arthritis. Arthritis Rheum 2000;43:563-5.

43 Chan ES, Cronstein BN. Molecular action of methotrexate in inflammatory disease. Arthritis Res 2002;44:266-73.

44 Gonzalez NJ, Isaacs LL. Evaluation of pancreatic proteolytic enzyme treatment of adenocarcinoma of the pancreas, with nutrition and detoxification support. Nutrition and Cancer 1999:33:117-24. 